Eur. J. Clin. Chem. Clin. Biochem.

Vol. 32, 1994, pp. 697-704

(c) 1994 Walter de Gruyter \& Co. Berlin - New York

\title{
Expression of the erb B Oncogene in the Morris Hepatoma 7777
}

\author{
By B. Hocher ${ }^{1,4}$, H. Abou-Rebyeh ${ }^{2,4}$, Martina Plaum ${ }^{1,4}$, Maryam Fakhury ${ }^{1,4}$, Sigrid Schiller ${ }^{3}$ and C. Bauer ${ }^{4}$ \\ 1 Abteilung fïr Allgemeine Innere Medizin und Nephrologie, Universitätsklinikum Benjamin Franklin \\ 2 Abteilung fïr Innere Medizin mit Schwerpunkt Gastroenterologie, Universitätsklinikum Benjamin Franklin \\ ${ }^{3}$ Abteilung fiir Radiologische Diagnostik und Nuklearmedizin, Universitätsklinikum Benjamin Franklin \\ ${ }^{4}$ Institut fiir Molekularbiologie und Biochemie \\ der Freien Universität Berlin, Berlin, Germany
}

(Received May 16/July 4, 1994)

Summary: Altered expression of protooncogenes/oncogenes is believed to be involved in hepatocarcinogenesis of the chemically induced, transplantable Morris hepatoma 7777. We compared the mRNA expression of $\mathrm{c}-\mathrm{N}$-ras and v-erb B mRNA of normal rat liver with that of Morris hepatoma 7777 using Northern blot analysis and in situ hybridization. Northern blot analysis revealed a strong overexpression of the v-erb B related mRNA, while the c$\mathrm{N}$-ras mRNA was only slightly increased. In situ hybridization using a $\mathrm{c}-\mathrm{N}$-ras mRNA probe also showed only a slighly increased number of silver grains in the hepatoma cells compared with normal rat liver. On the other hand, the v-erb $B$ related mRNA was strongly overexpressed in the hepatoma cells, while the connective-tissue capsule, the blood vessels, blood cells and the necrotic foci did not show an elevated v-erb B related gene mRNA expression. Similar results were obtained in liver metastases. The detectable v-erb B hybridization signal was lost by pretreatment with RNase A. We conlcude that the $\mathrm{c}-\mathrm{N}$-ras gene is of minor importance in the chemically induced, transplantable Morris hepatoma 7777, while the increased expression of the v-erb B related mRNA is due to a selection of ligand-independent tyrosine kinase activity.

\section{Introduction}

Wide variation of primary liver cancer incidence in different areas of the world suggests the involvement of environmental factors in its aetiology. Two major classes of risk factors (infection by the hepatitis $\mathrm{B}$ or $\mathrm{C}$ virus and many organic chemicals, e.g. the aflatoxins) have been identified in humans (1). Well known chemically induced animal models of hepatocarcinogenesis are the so called Morris hepatomas.

In the $1950 \mathrm{~s}, H .-P$. Morris developed a tumour model for chemically inducible, transplantable liver tumours in rats for studying histological, biological, and biochemical processes in hepatocarcinogenesis (2). Different substances, such as mono- and polycyclic aromatic amines and aflatoxin $B$, were tested. Besides liver neoplasia, the animals frequently developed lung carcinoma (predominantly males) or breast cancer (females). The primary tumour investigated in our study, Morris hepatoma 7777, was induced in female buffalo rat by administration of $\mathrm{N}$-2-fluorenylphthalamic acid (2-4).

There are many differences in the biochemical properties of normal rat liver and Morris hepatomas, e. g. different glycosylation pattern and glycoprotein turnover $(5,6)$, but the precise target of $\mathrm{N}$-2-fluorenylphthalamic acid carcinogenicity is not well defined. There is accumulating evidence that altered expression of specific cellular protooncogenes is involved in hepatocarcinogenesis $(7,8)$. Our interest has been focused on the v-erb B and $\mathrm{c}-\mathrm{N}$-ras genes. The v-erb B oncogene is homologous to the chicken epithelial growth factor (EGF) receptor, which lacks its extracellular epithelial growth factor binding domain and has some additional point mutations. Also, v-erb B has ligand-independent tyrosine kinase activity (9). Phosphorylation of protein-bound tyrosine is a key event in the control of normal and cancer cell proliferation (10). The gene product of the N-ras 
gene is a $M_{\mathrm{r}} 21000$ protein that binds guanine nucleotides with high affinity, as well as exhibiting GTPaseactivity $(11-13)$. Several chemically induced mutations of the wild-type ras protein have been reported. Most of them either show a reduced GTPase activity or a marked decrease in the exchange rates of guanine nucleotides $(14,15)$. These proteins often remain in their GTPbound form and can transform cells.

In the present study we compared the mRNA expression of the $\mathrm{c}-\mathrm{N}$-ras gene (a protoocogene that is often involved in chemically induced tumors) and the v-erb $\mathrm{B}$ oncogene (a tumour virus oncogene that is not known to be involved in chemical carcinogenicity) in normal rat liver with that of Morris hepatoma 7777, using Northern blot analysis. We also examined individual cells of the Morris hepatoma 7777 with recognizable morphological features, using in situ hybridization.

\section{Materials and Methods}

Materials

Unless otherwise stated, all reagents were of analytical grade and were purchased from Merck (Darmstadt, Germany), BoehringerMannheim (Mannheim, Germany) and Sigma (München, Germany). The v-erb B probe (9) and the c-N-ras (11) were from Dianova (Hamburg, Germany). Investigations were performed using male and female Buffalo rats, weighing $250 \mathrm{~g}$ each at the beginning of the experiments. They were fed on a commercial diet, with water ad libitum.

\section{Tumour transplantation}

A Buffalo rat with a tumour of $2-4 \mathrm{~cm}$ in diameter in the hindlimb was perfused with $9 \mathrm{~g} / 1 \mathrm{NaCl}$ solution via the portal vein under deep ether anaesthesia, and the encapsulated tumour was removed from the hindlimb. A $0.5 \mathrm{~mm}^{3}$ portion from a non-necrotic area of the tumour was collected, minced with an injection needle and resuspended in $9 \mathrm{~g} / 1 \mathrm{NaCl}$ solution. This suspension $(0.5 \mathrm{ml})$ was then injected into both hindlimbs of the recipient rat with a sterile syringe. The hepatoma attains a size of $2-4 \mathrm{~cm}$ in diameter within 14 to 16 days. Tumours in the liver were induced in healthy rats by injecting $0.08 \mathrm{ml}$ of the tumour cell suspension into the liver under visual control.

\section{Northern blot}

\section{RNA extraction and Northern blot analysis}

Total RNA was extracted from frozen liver and hepatoma tissue using the guanidinium isothiocyanate method and centrifugation through $\mathrm{CsCl}$ gradient as described by Sambrook et al. (16). Total RNA (15 $\mu \mathrm{g}$ per lane) was separated electrophoretically on a formamide/formaldehyde-agarose gel, blotted to Hybond N nylon membranes (Amersham, Arlington) and irradiated with UV light. After prehybridization for $2 \mathrm{~h}$ at $42^{\circ} \mathrm{C}$, the membranes were hybridized with $\left[{ }^{32} \mathrm{P}\right] \mathrm{dATP}$-labelled cDNA probes for $12 \mathrm{~h}$ at $42^{\circ} \mathrm{C}$. Blots were washed at $65^{\circ} \mathrm{C}$ with high stringency. Autoradiography was performed at $-80^{\circ} \mathrm{C}$ according to Sambrook et al. (16). The autoradiographs were analysed using a computer aided densitometer (ScanPack ${ }^{\mathrm{TM}}$ Scanner-Densitometer).

\section{Hybridization probes}

We used a 1700 bases v-erb B EcoR V fragment (9) subcloned in pBluescript 2+ SK plasmid (Stratagene, LaJolla, USA), a 1500 bases $\mathrm{N}$-ras $E$ co $\mathrm{R} V$ fragment (11) subcloned in pBluescript $2+$ SK plasmid and a 500 bases rat actin fragment subcloned in pGem 7Z. The fragments were excised from $\mathrm{pBS}$ plasmid, labelled by the random priming method with [ $\left.{ }^{32} \mathrm{P}\right] \mathrm{dATP}$, giving a specific activity of $1-3 \times 10^{9}$ counts $/ \mathrm{min} \cdot 1$ hybridization solution.

In situ hybridization

$$
\cdot 1
$$

\section{Tissue preparation}

Hepatoma and liver samples were immediately frozen in liquid nitrogen and stored at $-70^{\circ} \mathrm{C}$. Cryostat sections $(5 \mu \mathrm{m})$ were placed on siliconized slides treated with 3-amino-propyltriethoxysilane for better adherence, and dried on a hot plate at $80^{\circ} \mathrm{C}$ for $3 \mathrm{~min}$. Tissue sections were fixed in $40 \mathrm{~g} / 1$ paraformaldehyde in phosphate-buffered saline ( $\mathrm{pH}$ 7.4) for $20 \mathrm{~min}$ and dehydrated in graded ethanol.

\section{Probes}

A 1700 bases v-erb B EcoR V fragment (9) subcloned in pBluescript 2+ SK plasmid (Stratagene, LaJolla, USA), a 1500 bases N-ras EcoR V fragment (11) subcloned in pBluescript $2+$ SK plasmid and a 500 bases rat actin fragment subcloned in pGem $7 Z$ were used (see above). The plasmids were linearized with either $X h o 1$ or Sst2. Single-stranded RNA probes, complementary (antisense probe) or anticomplementary (sense probe, negative control) to cellular RNA, were obtained by run-off transcription with $\mathrm{T} 7$ or T3 RNA polymerase (Transcription Kit from Boehringer Mannheim). For labelling of RNA probes, ${ }^{35} \mathrm{~S}$-labelled UTP was used. Specific activity of the probes was $1.0-1.5 \times 10^{9}$ counts $/ \mathrm{min}$ - mg RNA. Better tissue penetration of the probes was achieved by controlled alkaline hydrolysis so that the RNA length was reduced to $50-200$ base pairs.

\section{In situ hybridization}

Prehybridization, hybridization, washing, RNase A digestion to remove non-specifically bound probe, and autoradiography were performed with modifications as described by Milani et al. $(17,18)$. Briefly, tissue sections were treated with $0.2 \mathrm{~mol} / \mathrm{l} \mathrm{HCl}$ for $20 \mathrm{~min}$, digested in $125 \mathrm{mg} / \mathrm{l}$ pronase (Boebringer-Mannheim, Mannheim, Germany) for $10 \mathrm{~min}$ at $22^{\circ} \mathrm{C}$, rinsed in $0.1 \mathrm{~mol} / \mathrm{l}$ glycine/phosphate buffered saline, washed in phosphate buffered saline, fixed again in $40 \mathrm{~g} / \mathrm{l}$ paraformaldehyde in phosphate buffered saline for $15 \mathrm{~min}$, acetylated in a solution of acetic anhydride $/ 0.1 \mathrm{~mol} / \mathrm{l} \mathrm{trie-}$ thanolamine, pH 8.0 (dilution $1: 400$ ), rinsed again in phosphate buffered saline, dehydrated in graded ethanol and air-dried. Each slide was covered with $0.025 \mathrm{ml}$ hybridization mixture containing $1-3 \times 10^{5}$ counts/min of labelled RNA probe in $50 \%$ formamide/ $10 \%$ dextran sulphate $/ 10 \mathrm{mmol} / 1$ dithiothreitol$/ 10 \mathrm{mmol} / \mathrm{l}$ Tris- $\mathrm{HCl}$, $\mathrm{pH} 7.5 / 10 \mathrm{mmol} / 1 \mathrm{Na}_{2} \mathrm{HPO}_{4} / 0.3 \mathrm{~mol} / 1 \mathrm{NaCl} / 5 \mathrm{mmol} / 1$ EDTA $/ 200$ $\mathrm{mg} / \mathrm{l}$ yeast $\mathrm{tRNA}$. Sections were sealed with a siliconized coverslip. After $18 \mathrm{~h}$ of incubation at $50^{\circ} \mathrm{C}$ in a humid chamber, slides were washed for $4 \mathrm{~h}$ at $60^{\circ} \mathrm{C}$ in a solution of $50 \%$ formamide, $10 \mathrm{mmol} / \mathrm{l}$ dithiothreitol in 1:10 diluted "salt" (stock solution $3 \mathrm{~mol} / 1 . \mathrm{NaCl}$, $0.1 \mathrm{~mol} / \mathrm{l} \mathrm{Tris} / \mathrm{HCl}(\mathrm{pH} 7.5), 0.1 \mathrm{~mol} / 1$ sodium phosphate (pH 6.8), $0.05 \mathrm{~mol} / \mathrm{I}$ EDTA (pH 8.0) in water, containing diethylpyrocarbonate treated water, volume fraction 0.1 ), for $15 \mathrm{~min}$ in $10 \mathrm{mmol} / 1$ Tris- $\mathrm{HCl}$, pH $7.5 / 0.5 \mathrm{~mol} / 1 \mathrm{NaCl} / 1 \mathrm{mmol} / \mathrm{l}$ EDTA at $37^{\circ} \mathrm{C}$, digested with RNase $A$ to reduce background caused by non-specific binding, again washed in $10 \mathrm{mmol} / 1$ Tris- $\mathrm{HCl}, \mathrm{pH} 7.5 / 0.5 \mathrm{~mol} / \mathrm{l}$ $\mathrm{NaCl} / 1 \mathrm{mmol} / \mathrm{l} \mathrm{EDTA}$ for $30 \mathrm{~min}$, then finally rinsed in saline sodium citrate buffer ( $\mathrm{pH}$ approx. 7.0), stock solution $0.3 \mathrm{~mol} / \mathrm{l}$ sodium citrate, $3 \mathrm{~mol} / 1 \mathrm{NaCl}$, diluted $1: 10,1: 200$ and $1: 400$ for 20 min each at $22^{\circ} \mathrm{C}$. The slides were dehydrated in graded ethanol, air dried and dipped into Ilford K5 photoemulsion (Ilford, Mobberley Cheshire, England). After exposure for 19-28 days at $4{ }^{\circ} \mathrm{C}$, sections were developed for 2.5 min using the Kodak D 19 developer (Kodak, Hemel Hampstead, England), afterwards rinsed in $10 \mathrm{~g} / \mathrm{l}$ acetic acid, fixed in Kodak fixer for $2.5 \mathrm{~min}$, washed in 
$\mathrm{H}_{2} \mathrm{O}$, then counterstained with hematoxylin-eosin. All hepatoma and normal liver tissues were simultaneously processed using the same probes and reagents.

\section{Control experiments}

The following control experiments were performed:

i) as a positive control for intact tissue, in situ hybridization was done with sense and antisense actin probes subcloned in pGem 7Z;

ii) as proof that the in situ hybridzation signal obtained was due to RNA-RNA hybridization, some hepatoma and liver sections were pretreated with RNase A prior to hybridization according to Cohen et al. (19). These slides were incubated in a solution of $50 \mathrm{~g} / 1$ RNase $A$ in saline sodium citrate buffer ( $\mathrm{pH}$ approx. 7.0), stock solution $0.3 \mathrm{~mol} / \mathrm{l}$ sodium citrate, $3 \mathrm{~mol} / \mathrm{l} \mathrm{NaCl}$, diluted $1: 10$ for $30 \mathrm{~min}$ at $37^{\circ} \mathrm{C}$, afterwards washed in saline sodium citrate buffer (pH approx. 7.0), stock solution $0.3 \mathrm{~mol} / \mathrm{l}$ sodium citrate, $3 \mathrm{~mol} / 1$ $\mathrm{NaCl}$, diluted $1: 10$ for $15 \mathrm{~min}$, then submitted to the same hybridization procedure as described above;

iii) sense and antisense v-erb $\mathrm{B}$ and $\mathrm{c}-\mathrm{N}$-ras probes were used in each experiment.

\section{Results}

\section{Northern blot analysis}

Northern blot analysis was performed to estimate the levels of v-erb B related sequences and the c-N-ras mRNA in rat liver and Morris hepatoma. The Northern blot analysis was performed with $15 \mu \mathrm{g}$ of total RNA per lane as described under Materials and Methods. The same messenger RNA transcripts, about 3600 and 1700 bases long, were detected in all of the liver and hepatoma samples using the v-erb $B$ probe. Compared with rat liver, the transcription levels of $\mathrm{v}$-erb $\mathrm{B}$ related sequences were strongly increased in the hepatoma (fig.

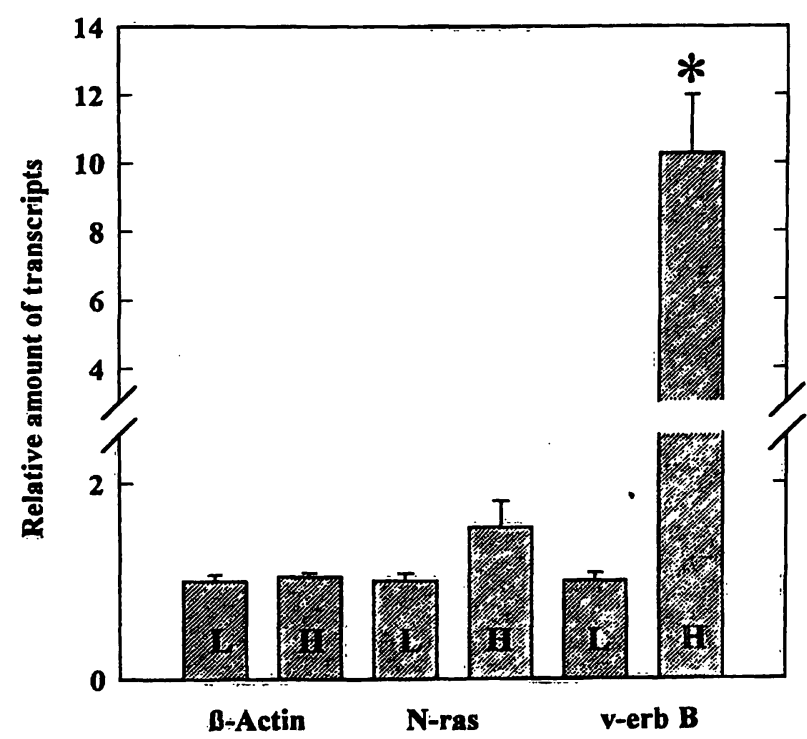

Fig. 1 Histogram of Northern blot analysis showing expression of $\beta$-actin, $c-N$-ras and v-erb $B$ related sequences ( \pm S.D.) in normal rat liver (L) and Morris hepatoma $7777(\mathrm{H})$. Expression of $\beta$ actin, $\mathrm{c}-\mathrm{N}$-ras and $\mathrm{v}$-erb $\mathrm{B}$ in rat liver was defined as $100 \%$. The Northern blots were analysed using a densitometer. $(n=6, *$ indicates $\mathrm{p}<0.001$ compared with normal rat liver)
1), whereas we saw only a slight increase in c-N-ras mRNA expression in Morris hepatoma 7777 compared with normal rat liver (fig. 1). The transcription levels of $\beta$-actin, a structural protein, were similar in liver and Morris hepatoma 7777.

\section{Histological characterization of the tumour}

Histologically, the tumour has the appearance of a rapidly growing, poorly differentiated hepatocellular carcinoma (fig. 2). The mitotic index was $1.7 \%$ $\pm 0.15 \%$ (mean \pm S. D.) in Morris hepatoma 7777 and $<0.1 \%$ in normal rat liver. The histological appearance of the hepatoma is characterized by the following features:

a) multiple necrotic foci,

b) connective-tissue capsule surrounding the tumour,

c) tumour cells of varying size,

d) basophilic cytoplasm,

e) pleomorphic, large cellular nuclei with prominent nucleoli,

f) loss of sinusoidal architecture,

g) absence of Kupffer's star cells.

The tumour raised in rat liver has a similar histological appearance (see (a) - (g)). In addition, there is compression of surrounding liver tissue and pronounced leukocyte infiltration.

\section{In situ hybridization}

The mean values of the liver samples hybridized with the sense probe (control) were $1.1 \pm 0.4$ silver grains/ nucleus ( $v$-erb B) and $0.6 \pm 0.2$ silver grains/nucleus (c$\mathrm{N}$-ras). The hepatoma had a mean non-specific signal

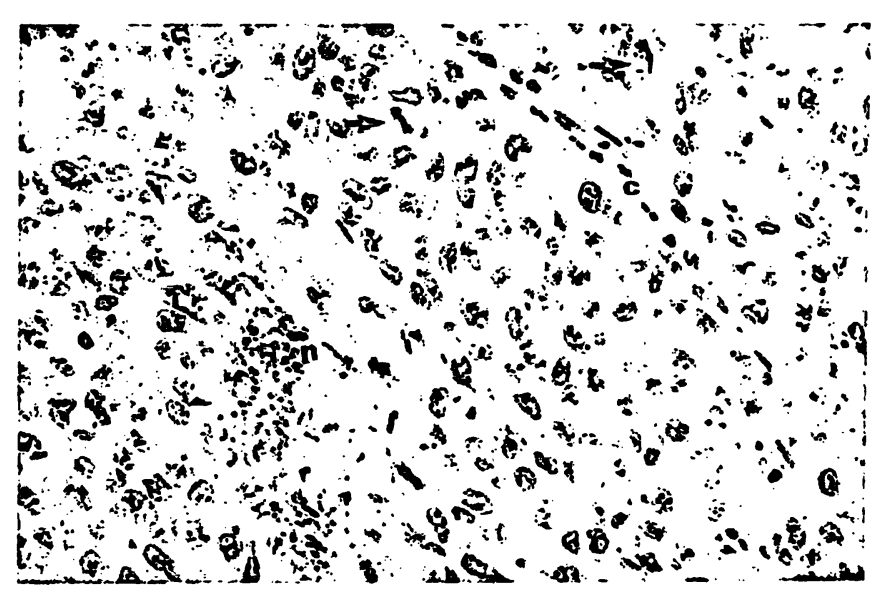

Fig. 2 Morris hepatoma in normal rat liver. The surrounding normal liver is not shown. HE staining. n: necrotic foci; c: conncctivetissue. Mitoses are marked with arrows. (Magnification: $\times 180$ ) 
density of $0.7 \pm 0.3$ silver grains/nucleus ( $v$-erb B) and $0.5 \pm 0.3$ silver grains/nucleus (c-N-ras). Note also the nearly background-free in situ hybridization in the marginal area of a hepatoma preparation with pronounced expression (fig. 3).

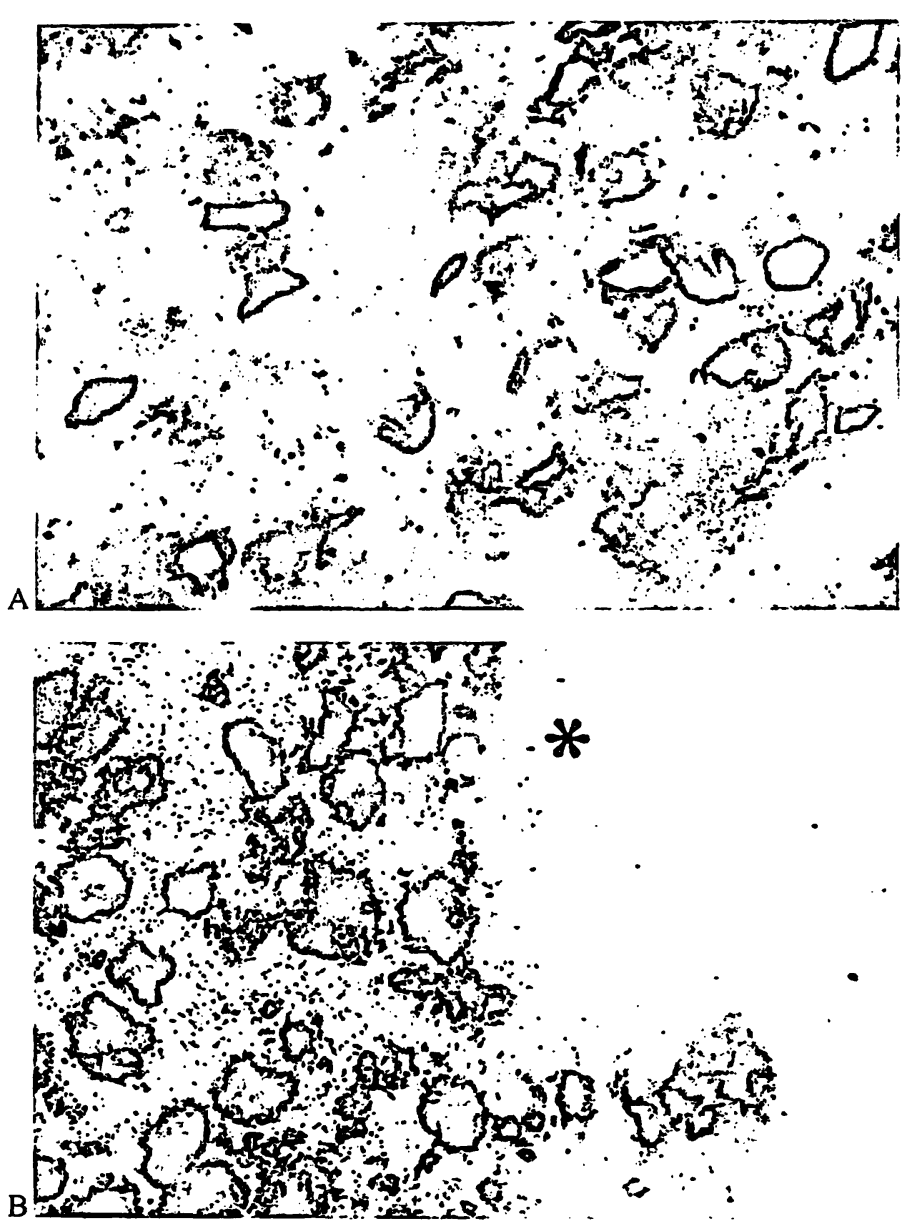

Fig. 3 In situ hybridization of normal rat liver and Morris hepatoma 7777 .

A: In situ hybridization of normal rat liver was performed according to Materials and Methods with ${ }^{35}$ S-labelled UTP-labelled verb B. Using the antisense probe, signals were mainly seen in the cytoplasm of hepatocytes. The signals were equally distributed throughout the liver preparation. Only rarely were silver grains seen in fibrocytes and endothelial cells of the vessels. Bile ducts and Kupffer's cells showed no silver grains.

B: Morris hepatoma 7777 showed an overexpression of signals in hepatoma cells (h). Note also the nearly background-free in situ hybridization in the marginal area of a liver preparation $\left(^{*}\right)$. (Magnification: $\times 450$ )

\section{v-erb $B$}

\section{Liver}

V-erb B-mRNA signals were primarily seen in the cytoplasm and around the nuclei of hepatocytes. The signal density of the antisense probe was $13.1 \pm 2.4$ silver grains/nucleus. The signals were equally distributed throughout the liver section (fig. 3). Silver grains were seen only rarely in fibrocytes and endothelial cells of the vessels. Bile ducts and Kupffer's cells showed no silver grains at all i.e., no v=erb B mRNA.

\section{Morris hepatoma 7777}

The tumour cells had a mean signal density (antisense probe) of $49.1 \pm 22.6$ silver grains/nucleus. Unlike healthy liver, the tumour preparations also showed signals above the nuclei. The nuclei of hepatoma cells were frequently surrounded by a rim of silver grains. Signals were absent from the connective-tissue capsule and the necrotic foci. The number of silver grains per hepatoma cell showed much wider variation than that of normal liver cells, but did not correlate with apparent morphological characteristics of the tumour cells, such as cell size, size and shape of the nucleus or cytoplasm etc. The v-erb B hybridization signal was lost by pretreatment with RNase A (fig. 4).

\section{Morris hepatoma normal in liver}

We primarily examined the area between normal liver tissue and malignant cells. It was noted that both areas were separated by extensive signal-free lymphocyte and leukocyte infiltrates. The liver cells adjacent to tumour cells showed a normal v-erb B expression. Necrotic areas in the metastases were likewise free of signal, as were the connective-tissue strands (fig. 4). The tumour cells showed the same signal pattern as described above.

\section{$C-N$-ras}

\section{Liver}

$\mathrm{C}-\mathrm{N}$-ras-mRNA signals were primarily seen in the cytoplasm and around the nuclei of hepatocytes. The signal
Fig. 4 In situ hybridization with a ${ }^{35} \mathrm{~S}$-labelled UTP-labelled verb B probe.

A: Morris hepatoma 7777 metastasis in normal rat liver. The hepatoma cells $(*)$ showed signals in the cytosol and the nucleolus. The signal density was increased severalfold in hepatoma cells com. pared with normal liver cells (l). The connective-tissue, the vessels (v) and blood cells (b) showed no expression of v-erb B related
mRNA. Silver grains are localized in the nuclei, but there is no preferential accumulation in the nucleoli.

B: No specific hybridization signal was obtained after RNase A pretreatment of the hepatoma with antisense v-erb $B$ probes.

$C$ : The sense control showed a low level of nonspecific hybridization. (Magnification: $\times 630$ ) 
Fa

a

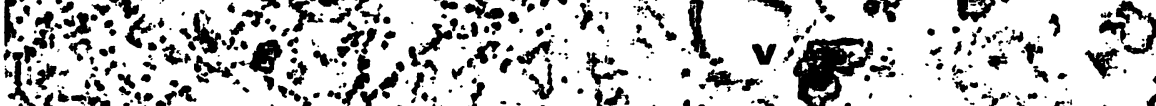

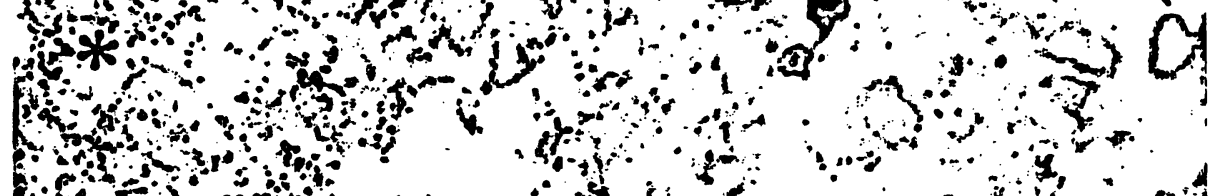

a

-

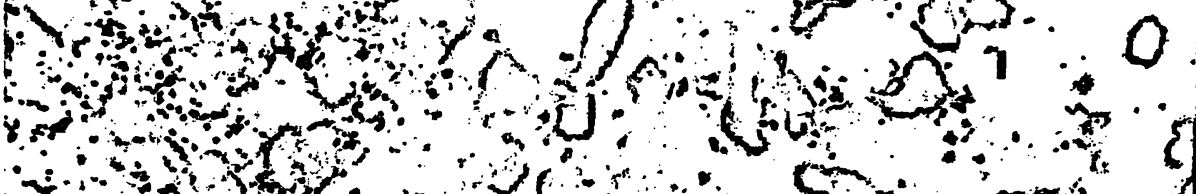
b

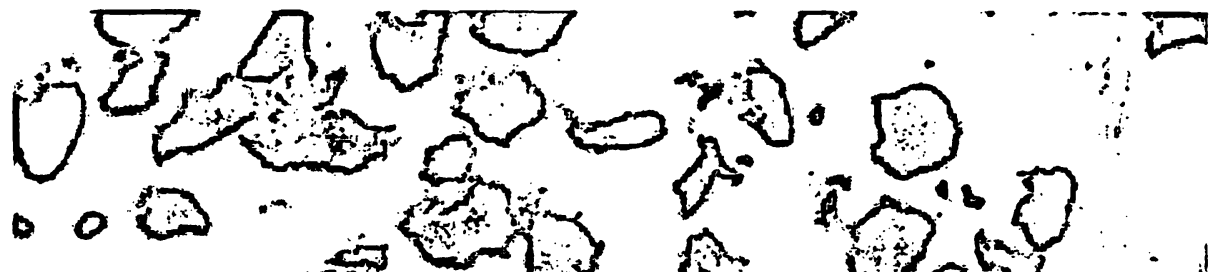

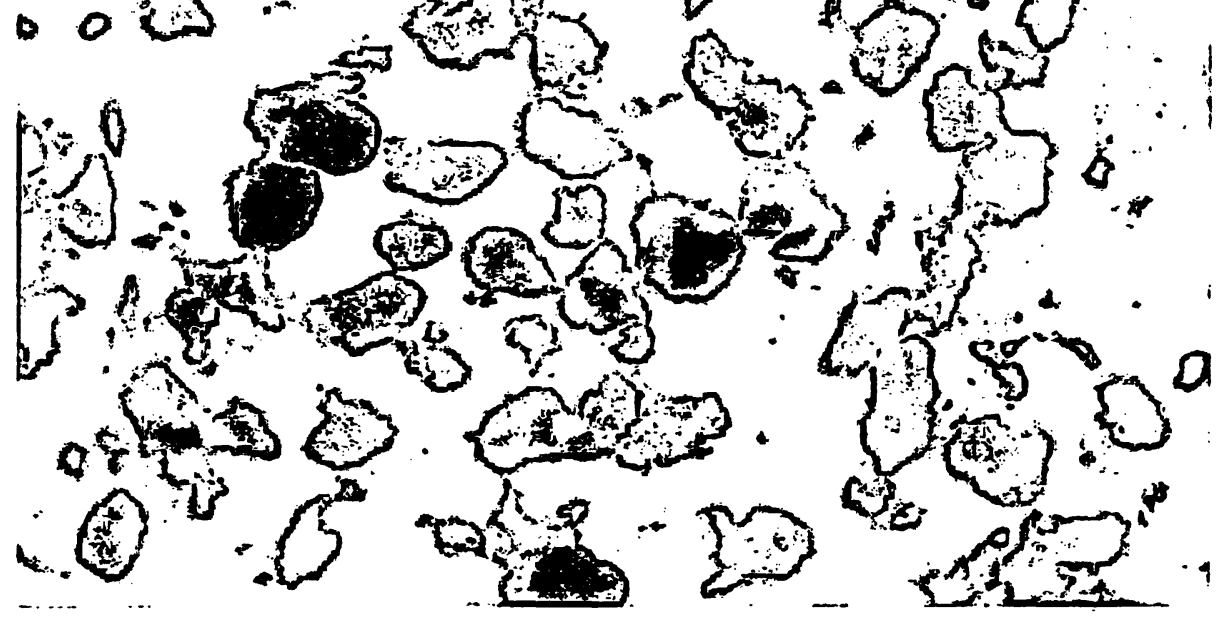

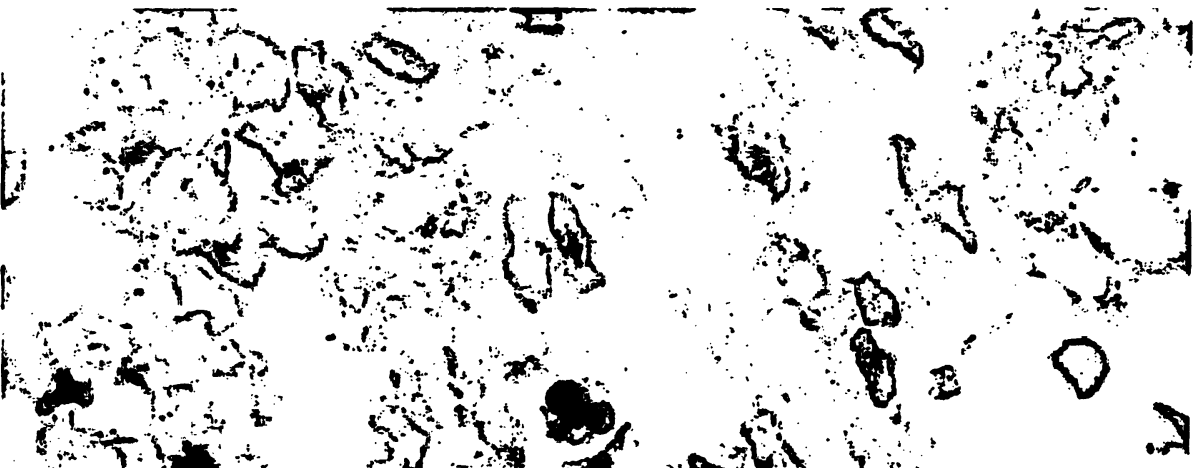

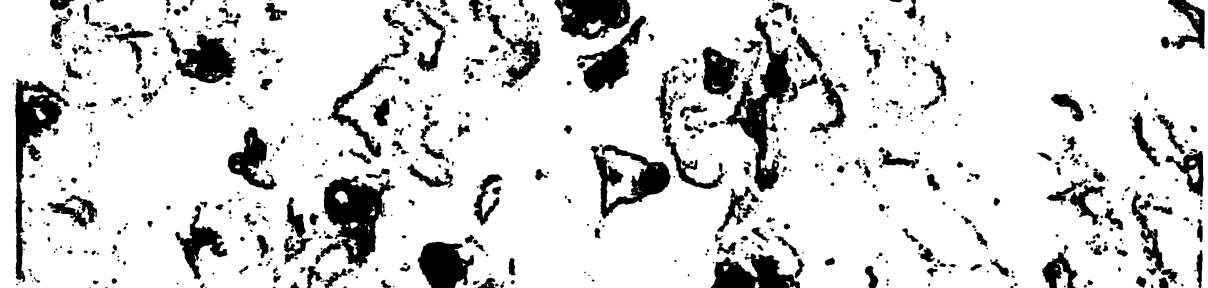

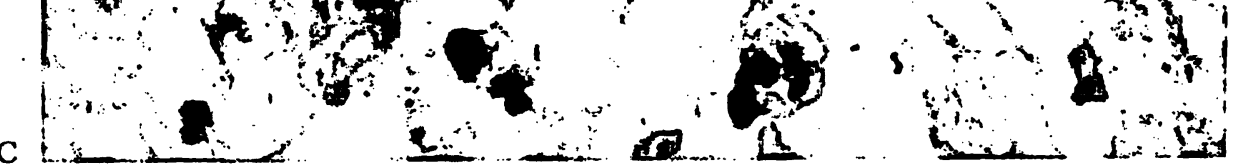


density of the antisense probe was $7.8 \pm 2.1$ silver grains/nucleus. The signals were equally distributed throughout the liver sections. However, some hepatocytes showed no silver grains. Bile ducts, fibrocytes, endothelial cells of the blood vessels and Kupffer's cells showed no detectable $\mathrm{c}-\mathrm{N}$-ras signal.

\section{Morris hepatoma 7777}

The tumour cells had a mean signal density (antisense probe) of $9.4 \pm 4.6$ silver grains/nucleus, but some cells did not express $\mathrm{c}-\mathrm{N}$-ras mRNA at all. The c-N-ras mRNA expression was only slightly increased compared with normal rat liver. Signals were absent from the connective-tissue capsule, the blood cells and the necrotic foci (data not shown).

\section{Discussion}

Extensive investigation of Morris hepatomas revealed no single, unique characteristic biochemical or genetic alteration leading to hepatocarcinogenesis (4-7). Moreover, the histological comparison of the primary hepatoma 7777 with the 300 transfer generation revealed a progressive dedifferentiation of the $\mathrm{N}$-2-fluorenylphthalamic acid induced, transplantable hepatoma. The Morris hepatoma was initially described as a well differentiated hepatoma with a slow growth rate $(2-4)$. During the past 30 years the growth rate has increased. After 300 transfer generations, we observed a dedifferentiated tumour with multiple necrotic foci, tumour cells of varying size, basophilic cytoplasm, pleomorphic, large cellular nuclei with prominent nucleoli, loss of sinusoidal architecture and absence of Kupffer's star cells (fig. 2).

Altered expression of protooncogenes is believed to be involved in hepatocarcinogenesis and dedifferentiation. The mammalian ras genes have been implicated in the genesis of a wide variety of chemically inducible liver tumours $(1,14,15)$. Although it is likely that the gene products play an essential role in signal transduction, their specific function is still unknown. Compared with normal liver, the Morris hepatoma showed only a slight increase in $\mathrm{c}-\mathrm{N}$-ras mRNA expression as demonstrated by Northern blot analysis and in situ hybridization (fig. 1). Therefore, an upregulation of the c-N-ras mRNA expression does not seem to be of major importance in the multistage process of carcinogen-induced carcinogenesis in the Morris hepatoma 7777. However, in many chemically induced hepatomas, point mutations have been reported within codons 12,13 and 61 , leading to a reduced GTPase activity or decreased exchange rate of guanine nucleotides $(1,20,21)$. These proteins remain in their
GTP-bound activated form, with their characteristic property of transforming liver cells. Our results did not exclude point mutations in the $\mathrm{c}-\mathrm{N}$-ras gene. Therefore, further studies are nessessary. In situ hybridization showed that $\mathrm{c}-\mathrm{N}$-ras mRNA was mainly expressed in the hepatoma cells. The expression rate showed a wide variation, some hepatoma cells had no specific c-N-ras signal, while others had more than 20 silver grains per cell. This may reflect the cell cycle related expression of the c-N-ras protein $(20,23)$. Maximal levels were seen in the mid to late $\mathrm{Gl}$ phase of the cell cycle.

Compared with the $c=\mathrm{N}$-ras mRNA, the v-erb B related mRNA was strongly overexpressed in the Morris hepatoma 7777 (fig. 1). Using Northern blot analysis, we detected v-erb B related sequences in rat liver and Morris hepatoma (about 3600 and 1700 bases long). We found a strong upregulation of $\mathrm{v}$-erb $\mathrm{B}$ related sequences in Morris hepatoma 7777. As seen with in situ hybridization (fig. 4) most of the detectable hybridization signal was lost by pretreatment with RNase. These results, and the observation that the erb B signals were mainly seen in the cytosol, indicate that under the conditions used in our study the hybridization signal reflects RNARNA hybrid formation and not DNA-RNA heterohybrid formation. The increased erb B mRNA levels in the Morris hepatoma 7777 were obviously not related to gene amplification. These data are in agreement with the results of Zhang et al. (31). He demonstrated (using Southern blot analysis) that gene amplification and apparent gene rearrangement were not responsible for the change in expression of erb B oncogene in Morris hepatoma. The full length rat EGF-receptor mRNA (about 10000,6000 and 2400 bases long) was not detectable with the probe used in our study, due to the high stringency hybridization conditions used in our study. The verb $B$ gene is related, but not identical, to the EGFreceptor. The in situ hybridization revealed a strong overexpression of the v-erb $B$ related gene in the hepatoma cells, while the connective-tissue capsule, the blood vessels, blood cells and the necrotic foci did not show an increased v-erb $B$ related gene mRNA signal (fig. 3 and 4). The v-erb $B$ gene encodes a membrane-associated glycoprotein that ranges in size from $M_{\mathrm{r}} 65000$ to $M_{\mathrm{r}}$ 73000 due to its varied degree of glycosylation. The $c$ erb B protooncogene product is homologous to the rat epidermal growth factor receptor and has a truncated extracellular ligand-binding site $(9,24)$. The v-erb B gene has some additional point mutations compared with the c-erb B gene $(24,28,29)$. The transmembrane and intracellular domain of the receptor has intact sequences. Amino-terminal truncation may be responsible for hepatocarcinogenesis by producing a ligand-independent receptor that has constitutive tyrosine kinase activity. Our data suggest that increased expression of the 
v-erb B related sequences upon serial tumour transplantation is due to a selection of ligand-independent tyrosine kinase activity, because these cells should have a growth advantage in vivo. On the other hand, the full length EGF-receptor mRNA seems to be decreased in some human or rat hepatomas $(25,26,27)$. Therefore, the increased formation of v-erb $B$ related gene transcripts suggests an alternative splicing or a selection of deletion mutations of the EGF receptor gene in Morris hepatoma 7777. Alternative splicing of the full-length rat EGF-receptor was seen in normal liver (28). Further studies are necessary to decide

i) whether the increased expression of erb B-related transcripts results in increased tyrosine kinase activity and

\section{References}

1. Wogan, G. M. (1992) Aflatoxins as risk factors for hepatocellular carcinoma in humans. Cancer Res. 52, 2114s-2118s.

2. Morris, H. P. (1965) Studies on the developement, biochemistry, and biology of experimental hepatomas. Adv. Cancer Res. 9, 228-296.

3. Morris, H. P. \& Wagner, B. P. (1968) Induction and transplantation of a rat hepatomas with different growth rate (including "minimal deviation" hepatomas). Meth. Cancer Res. 4, 125152.

4. Morris, H. P. \& Slaughter, L. J. (1977) Transplantable hepatomas. Adv. Exp. Med. Biol. 92, 1-19.

5. Nuck, R., Orthen, B. \& Reutter, W. (1992) Occurrence of alpha 1-2-fucosylation in membrane glycoproteins of Morris hepatoma 7777 but not in liver. Aberrant type of fucosylation in a malignant tissue. Eur. J. Biochem. 208, 669-676.

6. Tauber, R., Park, C. S., Becker, A., Geyer, R. \& Reutter, W. (1989) Rapid intramolecular turnover of N-linked glycans in plasma membrane glycoproteins. Extension of intramolecular turnover to the core sugars in plasma membrane glycoproteins of hepatoma. Eur. J. Biochem. 186, 55-62.

7. Fukuda, K., Kojiro, M. \& Chiu, J. F. (1993) Demonstration of extensive chromatin cleavage in transplanted Morris hepatoma 7777 tissue: Apoptosis or necrosis? Am. J. Pathol. 142, 935-946.

8. Hsieh, L. L., Shinozuka, H. \& Weinstein, I. B. (1991) Changes in expression of cellular oncogenes and endogenous retroviruslike sequences during hepatocarcinogenesis induced by a peroxisome proliferator. Br. J. Cancer 64, 815-820.

9. Vennstöm, B., Fanshier, L., Moscovici, C. \& Bishop, J. M. (1980) Molecular cloning of the avian erythroblastosis virus genome and recovery of oncogenic virus by transfection of chicken cells. J. Virol. $36,575-585$.

10. Ramponi, G., Ruggiero, M., Raugei, G., Berti, A., Modesti, A., Degl'Innocenti, D., Magnelli, L., Pazzagli, C., Chiarugi, V. R. \& Camici, G. (1992) Overexpression of a synthetic phosphotyrosine protein phosphatase gene inhibits normal and transformed cell growth. Int. J. Cancer 51, 652-656.

11. Hall, A., Marshall, C. J., Spurr, N. K. \& Weiss, R. A. (1983) Identification of transforming gene in two human sarcoma cell lines as a new member of the ras gene family located on chromosome 1. Nature 303, 396-400.

12. McCormick, F. (1989) Ras GTPase activating protein: Signal transmitter and signal terminator. Cell 56, 5-8.

13. Gibbs, J. B., Sigal, I. S., Poe, M. \& Scolnick, E. M. (1984) Intrinsic GTPase activity distinguishes normal' and oncogenic ii) whether selection upon serial tumour transplantation leads to an alternative splicing or deletion mutation of the EGF receptor gene in Morris hepatoma 7777.

Selection for EGF receptor alterations with high tumourigenic potential upon serial tumour transplantation are well known $(29,30)$. There are several known mutations leading to an increased tumorigenic potential, e.g. a Cterminal deletion which express non-downregulating epidermal growth factor receptors (30) or point mutations (Arg-263 to His, Ile-384 to Ser) (16).

\section{Acknowledgement}

We wish to thank Prof. Dr. W. Reutter, Berlin, for valuable discussion and critical reading of the manuscript. This study was supported by grants from Maria Sonnenfeld-Gedächtnis-Stiftung and the Fonds der Chemischen Industrie, Frankfurt/M., Germany.

ras p21 molecules. Proc. Natl. Acad. Sci. USA 81, 57045708.

14. Manne, V., Bekesi, E. \& Kung, H. (1985) Ha-ras proteins exhibit GTPase activity: Point mutations that activate Ha-ras gene products result in decreased GTPase activity. Proc. Natl. Acad. Sci. USA 83, 376-380.

15. Sweet, R. W., Yokoyama, S., Kamata, T., Feramisco, J. R., Rosenberg, M. \& Gross, M. (1984) The product of ras is a GTPase and the T24 oncogenic mutant is deficient in this activity. Nature $311,273-275$.

16. Sambrook, J., Fritsch, E. \& Maniatis, T. (1989) Molecular Cloning. A Laboratory Manual, secound edition Cold Spring Harbor Laboratory Press, USA.

17. Milani, S., Herbst, H., Schuppan, D., Kim, K. Y., Riecken, E. O. \& Stein, H. (1990) Procollagen expression by nonparenchy$\mathrm{mal}$ rat liver cells in experimental billary fibrosis. Gastroenterology 98, 175-184.

18. Milani, S., Herbst, H., Schuppan, D., Hahn, E. G. \& Stein, H. (1989) In situ hybridization for procollagen types 1,3 , and 4 mRNA in normal and fibrotic rat live: Evidence for predominant expression in nonparenchymal liver cells. Hepatology $10,84-92$.

19. Cohen, P. S., Seeger, R. C., Triche, T. J. \& Israel, M. A. (1988) Detection of N-myc gene expression in neuroblastoma tumors by in situ hybridization. Am. J. Pathol. 131, 391-397.

20. Chesa, P. G., Rettig, W., Melamed, M. R., Old, L. J. \& Niman, H. L. (1987) Expression of p21ras in normal and malignancy. Proc. Natl. Acad. Sci. USA 84, 3234-3238.

21. Challen, C., Guo, K., Collier, J. D., Cavanagh, D. \& Dassendine, M. E. (1992) Infrequent point mutations in codons 12 and 61 of ras oncogenes in human hepatocellular carcinomas. J. Hepatol. 14, 342-346.

22. Takada, S. \& Koike, K. (1989) Activated N-ras gene was found in human hepatoma tissue but only in a small fraction of the tumor cells. Oncogene 4, 189-193.

23. Lu, K. \& Campisi, J. (1992) Ras proteins are essential and selective for the action of insulin-like growth factor 1 in the $G_{1}$ phase of the cell cyclus in BALB/c murine fibroblasts. Proc. Natl. Acad. Sci. USA 89, 3889-3893.

24. Shu, H. K., Pelley, R. J. \& Kung, H. J. (1991) Dissecting the activating mutations in v-erbB of avian erythroblastosis virus strain R. J. Virol. 65, 6173-6180.

25. Francavilla, A., Panella, C., Amoruso, A., Giangaspero, A., Gennari, L., Mazzaferro, V., Bolella, G., van-Thiel, D. H. \& Starzl, T. E. (1991) Role of estrogens and epidermal growth 
factor in hepatocellular carcinoma (HCC). Dig. Dis. Sci. 36, 1299-1302.

26. Hsieh, L. L., Shinozuka, H. \& Weinstein, I. B. (1991) Changes in expression of cellular oncogenes and endogenous retroviruslike sequences during hepatocarcinogenesis induced by a peroxisome proliferator. Br. J. Cancer 64, 815-820.

27. Bartles, J. R., Khuon, S., Lin, X., Zhang, L., Reddy, J. K., Rao, M. S., Isoye, S. T., Nehme, C. L. \& Fayos, B. E. (1990) Peroxisome proliferator-induced alterations in the expression and modification of rat hepatocyte plasma membrane. Cancer Res. 50, 669-674.

28. Petch, L. A., Harris, J., Raymond, V. W., Blasband, A., Lee, D. \& Earp, H. S. (1990) A truncated, secreted form of the epidermal growth factor receptor is encoded by an alternatively spliced transcript in normal rat tissue. Mol. Cell. Biol. 10, 2973-2982.

29. Ekstrand, A. J., Sugawa, N., James, C. D. \& Collins, V. P. (1992) Amplified and rearranged epidermal growth factor genes in human glioblastomas reveal deletions of sequences encoding portions of the $\mathrm{N}$ - and/or C-terminal tails. Proc. Natl. Acad. Sci. USA 89, 4309-4313.

30. Mansui, H., Wells, A., Lazar, C. S., Rosenfeld, M. G. \& Gill, G. (1991) Enhanced tumorigenesis of NR6 cells which express non-downregulating epidermal growth factor receptors. Cancer Res. 51, 6170-6175.

31. Zhang, X. K., Wang, Z., Lee, A.,'Huang, D. P. \& Chiu, J. F. (1988) Differential expression of cellular oncogenes during rat liver development. Cancer Lett. 41, 147-155.

\section{Dr. Berthold Hocher}

Universitätsklinikum Benjamin Franklin der Freien Universität Berlin

Abteilung für Innere Medizin - Nephrologie

Hindenburgdamm 30

D-12200 Berlin

Germany 